\title{
Ahvenen ja särjen marinointi
}

\author{
Mailis Kuuppo, Juha Koivurinta ja Pekka Koivistoinen \\ Elintarvikekemian ja -teknologian laitos (EKT), Helsingin yliopisto, 00710 \\ Helsinki 71
}

\section{Marinating of roach (Rutilus rutilus) and perch (Perca fluviatilis)}

Mailis KuUppo, Juha Korvurinta and Pekka Korvistoinen

Department of Food Chemistry and Technology, University of Helsinki, 00710 Helsinki 71

\begin{abstract}
Processing conditions appropriate for small scale canning stations were selected for roach (Rutilus rutilus) and perch (Perca fluviatilis) in respect to acetic acid and salt concentrations, time and temperature, size of fish, and storage keepability with or without preservatives at different temperatures when packed in glass or plastic jars.

The optimum marinating times for perch varied from 1 to 5 days and for roach from 2 to 6 days depending on the marinating temperature, the size of the fish and whether the fish was precooked or not before marinating.

During a storage period of 6 months only slight or no changes in organoleptic scores, $\mathrm{pH}$ and total numbers of bacteria were observed in the marinades in relation to storage time, temperature and packing material.
\end{abstract}

\section{Johdanto}

Marinointi on eräs vanhimpia kalan säilöntämenetelmiä.! Marinadien raakaaineena käytetään yleisimmin silliä ja silakkaa joko tuoreena, pakastettuna tai suolattuna (MEYER 1965). Marinoinnilla tarkoitetaan tässä kalan säilömistä etikka-suolaliemeen, jonka happo- ja suolapitoisuuksiin marinadien säilyvyys perustuu. Kypsyminen kestää $2-4$ vuorokautta ja sen aikana muodostuu kalamarinadeille tyypillisiä haju- ja makuaineita. Lopullinen haju ja maku saadaan aikaan sokeria ja mausteita lisäämällä. Koska etikka- ja suolapitoisuutta ei tuotteen maun vuoksi voida nostaa kovin korkealle, kalamarinadit säilyvät vain rajoitetun ajan ja ne luokitellaan siten puolisäilykkeiksi. Säilyvyyden parantaminen kuumennuskäsittelyllä ei ole yleensä mahdollista, koska marinadille ominaiset piirteet tällöin katoavat. Vain ns. paisto- ja keittomarinadeja valmistettaessa käytetään kuumennuskäsittelyä (MEYER 1965). Valmistustavan perusteella voidaankin erottaa kolme eri marinadityyppiä: kylmä- 
marinadit, keittomarinadit ja paistomarinadit. Kylmämarinadit valmistetaan upottamalla peratut kalat tai kalafileet etikkaa, suolaa, sokeria ja mausteita sisältävään marinointiliemeen. Etikka- ja suolakonsentraatiot sekä kala: liemi-suhde vaihtelevat $\mathrm{mm}$. kalalajin ja vuodenajan mukaan. Marinointi kestää $10^{\circ}-12^{\circ} \mathrm{C}$ :ssa $3-5$ vuorokautta. Tämän jälkeen kalat pakataan fileinä tai paloiteltuina tölkkeihin ja päälle kaadetaan marinointilientä tai jotain muuta maustettua kastiketta. Marinadien varastointipakkauksina käytetään yleensä lasi-, pelti- ja muovitölkkejä, toisinaan myös muovipusseja (MEYER 1965).

Elintarvikekemian ja -teknologian laitoksessa suoritetun tutkimuksen tavoitteena oli etsiä optimaaliset prosessointiolosuhteet ahvenen ja särjen marinointia varten. Työ kuuluu osana kolmivuotiseen tutkimukseen, jonka tarkoitus on kehittää kalojen piensäilöntään soveltuvat säilöntämenetelmät lähinnä ahvenen ja särjen jalostamiseksi hyväksyttäviksi täys- ja puolisäilykkeiksi. Marinoinnin osalta etsittiin säilyvyyden ja maun kannalta optimaaliset etikkaja suolakonsentraatiot sekä optimaalinen marinointiaika kahdessa eri lämpötilassa. Lisäksi tutkittiin marinointilämpötilan, lisäaineiden, varastointilämpötilan ja pakkausmateriaalin vaikutusta tuotteen laatuun ja säilyvyyteen. Säilyvyyskokeet kestivät 6 kuukautta. Tutkimuskaaviot ahvenen ja särjen osalta on esitetty kuvina 1 ja 2 .

\section{Materiaalit ja menetelmät}

\section{Kalaraaka-aine}

Tutkimuksessa käytetty iso $(100-300 \mathrm{~g})$ ahven ja särki hankittiin Helsingin kalatukusta ja pieni $(10-40 \mathrm{~g})$ ahven ja särki yksityiseltä Bodom-järvellä Espoossa kalastavalta kalastajalta. Kalat toimitettiin henkilöautolla elintarvikekemian ja -teknologian laitokseen, missä ne käsiteltiin välittömästi.

\section{Marinointi}

Marinointiliemi valmistettiin väkiviinaetikasta (10\% etikkahappoa), karkeasta merisuolasta, sokerista ja mausteista seuraavan ohjeen mukaan:

\begin{tabular}{|c|c|}
\hline väkiviinaetikkaa .................... & 500 \\
\hline merisuolaa ........... & 100 \\
\hline 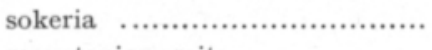 & 200 \\
\hline maustepippureita .................. & 3 \\
\hline valkopippureita .................... & 1.5 \\
\hline sinapinsiemeniä ................... & 1.5 \\
\hline tilliä & 1 \\
\hline laakerinlehtiä ........................ & 1 \\
\hline sipulia & 60 \\
\hline
\end{tabular}

Vettä lisättiin niin paljon, että lopputilavuudeksi saatiin 1 litra.

Etikka ja osa vedestä kuumennettiin kiehuvaksi ja seokseen lisättiin suola ja sokeri. Jäähtyneeseen liemeen lisätiin mausteet ja vesi. Marinointi suoritettiin muovisangoissa kylmämarinointimenetelmällä. 
Kuva 1. Marinoidun ahvenen tutkimuskaavio

Fig. 1. The research scheme for marinated perch

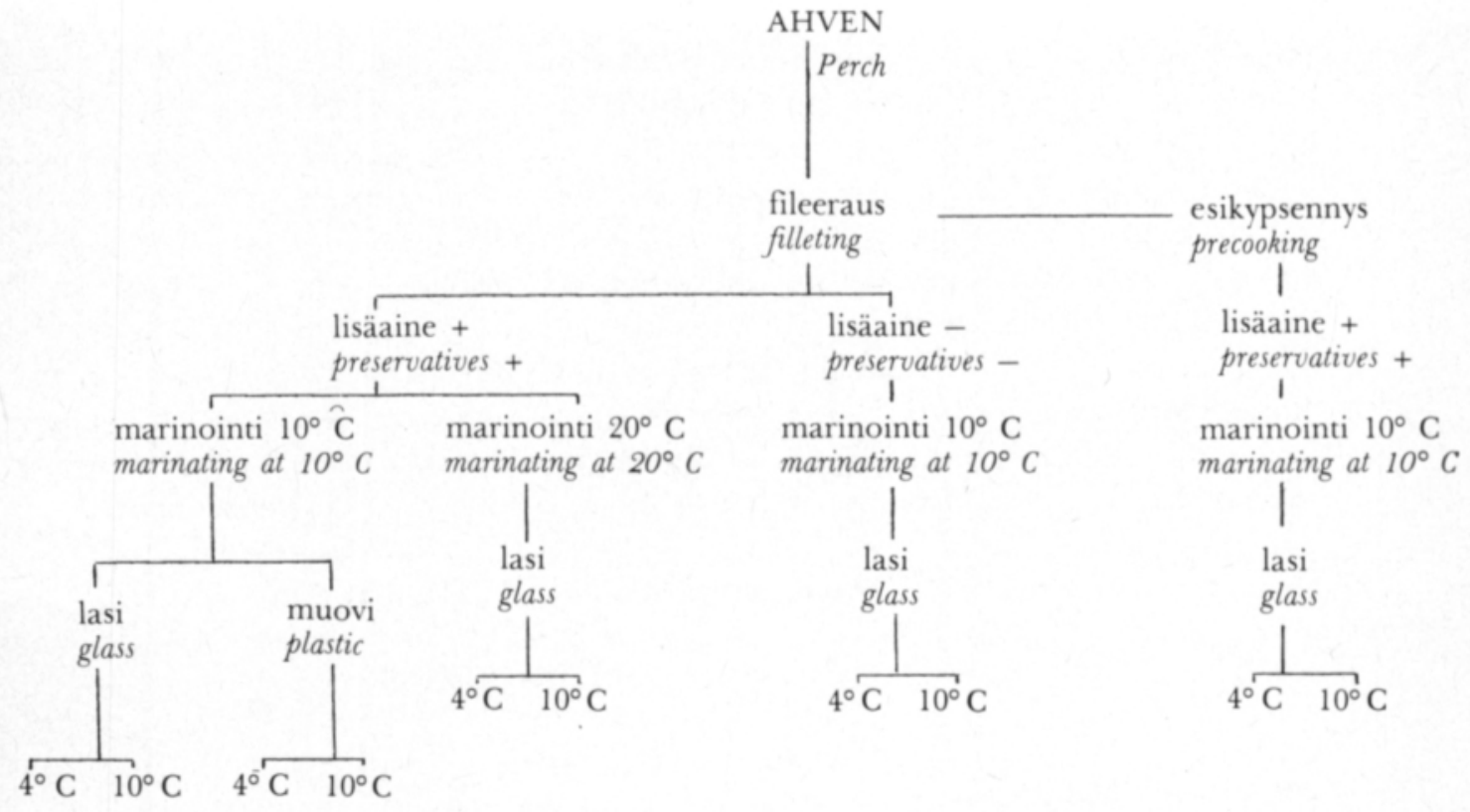

Kuva 2. Marinoidun särjen tutkimuskaavio

Fig. 2. The research scheme for marinated roach

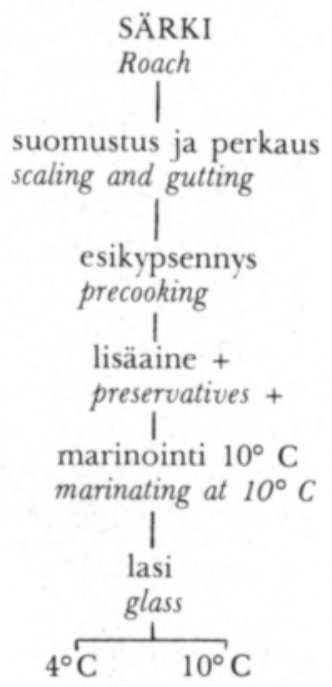


Suolapitoisuus määritettiin liemestä ja kalasta mukaellen AntonAcoPouLosin (1973) menetelmää. Erlenmeyeriin punnittiin tarkasti n. 2 g Ultra Turrax homogenisaattorilla (JANKE \& KunKEL KG, TP 18/2, $20000 \mathrm{r} / \mathrm{min}$ ) hienonnettua näytettä, lisättiin $\mathbf{5 0} \mathbf{~ m l}$ vettä, kuumennettiin ! kiehuvaksi ja annettiin kiehua hetken. Jäähtynyt liuos titrattiin $0.1 \mathrm{~N} \mathrm{AgNO}_{3}$-liuoksella $10 \% \quad \mathrm{Kr}_{2} \mathrm{CO}_{4}$-liuos indikaattorina. Tulos laskettiin seuraavasta kaavasta:

$$
\text { suolapitoisuus } \%=\frac{100 \times 5.845 \times 0.1 \mathrm{~N} \mathrm{AgNO}_{3} \text {-kulutus ml }}{\text { näytteen paino } \mathrm{mg}}
$$

Marinointiliemen ja kalan happopitoisuus etikkahapoksi laskettuna määritettiin Antonacopoulosin (1973) menetelmää mukaellen. $2 \mathrm{~g}$ homogenoitua näytettä laimennettiin $100 \mathrm{ml}$ :lla tislattua vettä erlenmeyerissä ja sekoitettiin hyvin. Seos kuumennettiin kiehumispisteeseen ja lyhyen seisotusajan (10 min.) jälkeen titrattiin $0.1 \mathrm{~N} \mathrm{NaOH}$ :lla fenolftaleiini indikaattorina. Happopitoisuus laskettiin kaavasta:

$$
\text { happopitoisuus } \%=\frac{0.1 \mathrm{~N} \mathrm{NaOH} \text {-kulutus } \mathrm{ml} \times 0.6}{\text { näytteen paino } \mathrm{g}}
$$

Marinointiliemen ja kalan $\mathrm{pH}$ mitattiin Radiometer pHM 26-mittarilla. Kala homogenoitiin Ultra Turrax-homogenisaattorilla (JANkE \& KUnKeL $\mathrm{KG}$, TP 18/2, $20000 \mathrm{r} / \mathrm{min}$ ) ennen $\mathrm{pH}$-mittausta. Suola- ja happopitoisuuksien määrittämistä ja pH-mittausta varten otettiin sekä kalasta että liemestä neljä rinnakkaisnäytettä.

\section{Mikrobiologiset määritykset}

Mesofiilisten, psykrofiilisten ja halofiilisten bakteerien sekä koliformipitoisuuden määritys suoritettiin Gyllenbergin ym. (1966) ja Sharfin (1966) mukaan. Rinnakkaismäärityksiä tehtiin kolme.

\section{Organoleptiset määritykset}

Marinoidun kalan ulkonäkö, rakenne, maku ja haju arvosteltiin aistinvaraisesti arvopistetestillä. Arvostelulomakkeessa maistajalta kysyttiin, onko näyte ulkonäöltään, rakenteeltaan, maultaan ja hajultaan erinomainen, hyväksyttävä vai kelvoton. Tuloksia tarkasteltaessa eri termeille annettiin pisteitä seuraavasti: erinomainen $=3$, hyväksyttävä $=2$ ja kelvoton $=1$.

Marinointilämpötilan, lisäaineiden käytön, pakkausmateriaalin ja varastointilämpötilan vaikutusta laatuun testattiin triangelitestillä. Arvostelun suoritti kahdeksan maistamiseen jonkin verran harjaantuneen henkilön ryhmä. Useimmat maistajista eivät olleet tottuneet marinoidun kalan makuun. Aistinvarainen arvostelu suoritettiin kaksi kertaa jokaista arviointikertaa kohden. 


\section{Säilyvyyskokeet}

Säilyvyyskokeet tehtiin isosta ahvenesta ja pienestä särjestä valmistetuilla marinadeilla. Säilyvyyskokeet kestivät 6 kuukautta. Fysikaaliset, kemialliset ja mikrobiologiset määritykset tehtiin 0,3 ja 6 kuukauden varastoinnin jälkeen. Yleislaatu (ulkonäkö, rakenne, maku ja haju) arvosteltiin aistinvaraisesti $10^{\circ} \mathrm{C}$ :ssa marinoiduista, lasiastioissa $4^{\circ} \mathrm{C}$ :ssa varastoiduista näytteistä $0,3,5$ ja 6 kuukauden varastoinnin jälkeen ja muista 6 kuukauden varastoinnin jälkeen. Marinointilämpötilan, pakkausmateriaalin ja varastointilämpötilan vaikutusta laatuun selvitettiin triangelitestillä 3,5 ja 6 kuukauden varastoinnin jälkeen.

\section{Tulokset}

\section{Marinointiaika ja -lämpötila}

Sopiva kala:liemi-suhde sekä eri lämpötiloissa tarvittavat marinointiajat selvitettiin esikokeiden avulla. Bakteeritoiminnan estämiseksi tuotteiden $\mathrm{pH}$ pyrittiin laskemaan alle 4.5. Kalojen kypsyyttä seurattiin mittaamalla pHarvot ja määrittämällä happo- ja suolapitoisuudet kalassa ja liemessä päivittäin. Kun pH sekä happo- ja suolapitoisuudet kalassa ja liemessä olivat tasoittuneet, valmisteen katsottiin olevan kypsä. Käytettäessä kala:liemi-suhdetta $3: 2 \mathrm{pH}$ ei laskenut alle 4.5 eivätkä kalat peittyneet kunnolla liemeen, minkä vuoksi kokeita jatkettaessa käytettiin suhdetta $1: 1$.

Marinoitaessa perattua tai nyljettyä isoa ahventa oli nahan ja ruotojen irroittaminen kaloista marinoinnin jälkeen vaikeaa, minkä vuoksi jatkossa ahvenet fileerattiin ennen marinointia. Fileet olivat joidenkin maistajien mielestä marinoinnin jälkeen hieman sitkeitä.

Sitkeyden poistamiseksi kokeiltiin minuutin esikypsennystä kiehuvassa vedessä ennen marinointia. Esikypsennetyt marinoidut fileet olivat pehmeitä ja hajosivat helposti niitä käsiteltäessä. Marinointiajat näkyvät taulukosta 1 .

Pienellä ahvenella kokeiltiin nyljetyn kalan marinointia. Kypsytysaika oli $10^{\circ} \mathrm{C}$ :ssa 3 vrk (taulukko 1). Kalat olivat melko pehmeitä ja ruodot irtosivat lihasta. Raaka-ainepulan vuoksi esikokeita pienellä ahvenella ei voitu jatkaa eikä varsinaisia säilyvyyskokeita suorittaa.

Isolla särjellä kokeiltiin sekä peratun että fileeratun kalan marinointia (taulukko 1).

Pientä särkeä marinoitiin aluksi perattuna, mutta kalat olivat kypsytyksen jälkeen sitkeitä ja ruotojen irrottaminen niistä oli vaikeaa. Aistinvaraisarvostelussa maistajat havaitsivat kaloissa mudan makua. Sivumaun peittämiseksi ja sitkeyden poistamiseksi kokeiltiin esikypsennystä ennen marinointia. Minuutin kuumennuksen kiehuvassa vedessä todettiin olevan esikypsennysmenetelmänä parempi kuin paistaminen öljyssä, koska paistaminen aiheutti epämiellyttävää sivumakua lopputuotteeseen. Maistettaessa esikypsennettyjä marinoituja särkiä vain yksi maistaja havaitsi niissä mudan makua. Esikypsennetyn pienen särjen kypsytysaika $10^{\circ} \mathrm{C}$ :ssa oli 2 vrk (taulukko 1). 
Taulukko 1. Ahvenen ja särjen marinointiajat $10^{\circ} \mathrm{C}$ :ssa ja $20^{\circ} \mathrm{C}$ :ssa.

Table 1. Marinating times for perch and roach at $10^{\circ} \mathrm{C}$ and $20^{\circ} \mathrm{C}$.

\begin{tabular}{|c|c|c|}
\hline $\begin{array}{l}\text { Marinoitava kala } \\
\text { Fish }\end{array}$ & $\begin{array}{c}\text { Marinointilämpötila }{ }^{\circ} \mathrm{C} \\
\text { Marinating } \\
\text { temperature }{ }^{\circ} \mathrm{C}\end{array}$ & $\begin{array}{c}\text { Marinointiaika vrk } \\
\text { Marinating time } \\
\text { days }\end{array}$ \\
\hline 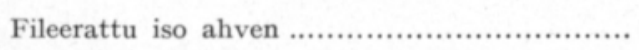 & 10 & 5 \\
\hline Fillets of big perch & 20 & 4 \\
\hline Fileerattu esikypsennetty iso ahven ................ & 10 & 2 \\
\hline Precooked fillets of big perch & 20 & 1 \\
\hline $\begin{array}{l}\text { Nyljetty pieni ahven } . . . \ldots \ldots \ldots \ldots \ldots \ldots \ldots \ldots \ldots \ldots \ldots \ldots \ldots \ldots \ldots \ldots \ldots \ldots \ldots \\
\text { Small perch }\end{array}$ & 10 & 3 \\
\hline 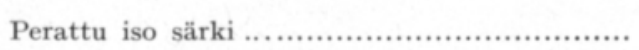 & 10 & 6 \\
\hline Big roach & 20 & 5 \\
\hline $\begin{array}{l}\text { Fileerattu iso särki } \\
\text { Fillets of big roach }\end{array}$ & 10 & 3 \\
\hline $\begin{array}{l}\text { Esikypsennetty pieni särki } \ldots \ldots \ldots \ldots \ldots \ldots \ldots \ldots \ldots \ldots \ldots \ldots \ldots \\
\text { Precooked small roach }\end{array}$ & 10 & 2 \\
\hline
\end{tabular}

Esikokeiden jälkeen suoritettiin marinointi säilyvyyskokeita varten. Ahvenia marinoitiin sekä raakoina että esikypsennettyinä fileinä. Esikypsennys suoritettiin upottamalla fileet lävikössä minuutiksi kiehuvaan veteen, minkä jälkeen ne nostettiin valumaan ja kuivumaan. Fileet marinoitiin vasta täysin jäähtyneinä. Pienet särjet esikypsennettiin samalla tavalla kuin ahvenfileet ennen marinointia. Marinoitavat ahvenfileet ja särjet punnittiin, ladottiin muovisankojen pohjalle ja päälle kaadettiin marinointiliemi. Kala:liemisuhde oli 1:1. Säilöntäaineiksi lisättiin natriumbentsoaattia $0.08 \%$ ja phydroksibentsoehapon metyyliesteriä $0.04 \%$ kalan ja liemen yhteispainosta. Kalat ja liemi sekoitettiin hyvin ja osa astioista siirrettiin $10^{\circ} \mathrm{C}: \mathrm{n}$ ja osa $20^{\circ} \mathrm{C}: \mathrm{n}$ varastoon.

Lisäaineiden vaikutuksen selvittämiseksi marinoitiin kontrollierä ahvenfileitä ilman lisäaineita $10^{\circ} \mathrm{C}$ :ssa.

Ahvenfileitä kypsytettiin $10^{\circ} \mathrm{C}$ :ssa 5 vrk ja $20^{\circ} \mathrm{C}$ :ssa 4 vrk, esikypsennettyjä ahvenfileitä ja särkiä $10^{\circ} \mathrm{C}$ :ssa 2 vrk. Kypsytyksen jälkeen kalat pakattiin $500 \mathrm{ml}: n$ lasitölkkeihin ja osa $10^{\circ} \mathrm{C}$ :ssa marinoiduista ahvenfileistä $500 \mathrm{ml}: \mathrm{n}$ muovitölkkeihin. Marinointilientä lisättiin niin paljon, että kala: liemi-suhteeksi saatiin $1: 1$. Puolet tölkeistä varastoitiin $4^{\circ} \mathrm{C}$ :ssa ja puolet $10^{\circ} \mathrm{C}$ :ssa säilytyslämpötilan vaikutuksen selvittämiseksi.

\section{Säilyvyyskokeet}

Särki

Särkimarinadissa kalan suolapitoisuus vaihteli välillä $4.6-5.1 \%$ ja liemen suolapitoisuus välillä $4.6-\mathbf{5 . 5} \%$ (kuva 3 ). $10^{\circ} \mathrm{C}$ :ssa varastoiduissa marinadeissa liemen ja kalan suolapitoisuudet olivat varastoinnin päätyttyä suurin piirtein yhtä suuret, noin $5.1 \%$. 


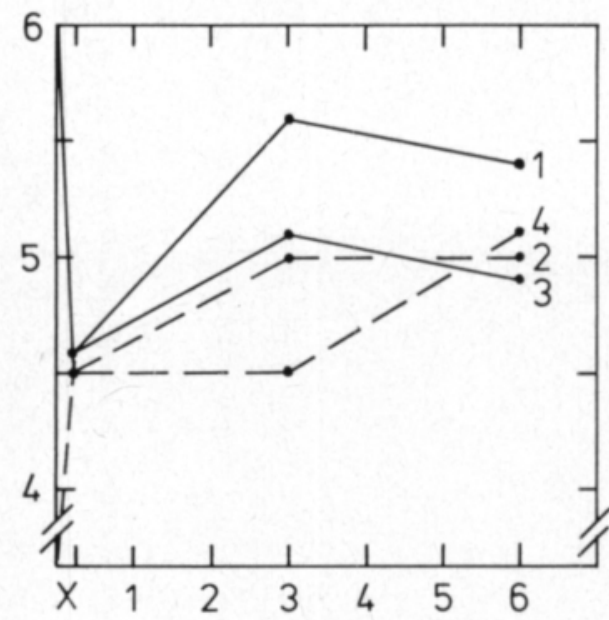

KUUKAUTTA
Kuva 3. Kalan ja liemen suolapitoisuuden muutokset sårkimarinadissa varastoinnin aikana.

1. varastoitu $4^{\circ} \mathrm{C}$ :ssa, kala

2. varastoitu, , liemi

3. varastoitu $10^{\circ} \mathrm{C}$ :ssa, kala

4. varastoitu, , liemi

Fig. 3. The changes in salt concentrations of fish and pickle in roach marinades during storage at $4^{\circ} \mathrm{C}$.

1. storad at $4^{\circ} \mathrm{C}$, fish

2. stored at, , pickle

3. stored at $10^{\circ} \mathrm{C}$, fish

4. stored at, , pickle

\section{MONTHS}

Särkimarinadien happopitoisuudet olivat säilyvyyskokeiden alkaessa 1.8 $1.9 \%$ ja muuttuivat vain vähän varastoinnin aikana. Särkimarinadien $\mathrm{pH}$ pysyi koko varastoinnin ajan välillä 4.4-4.6. Eri lämpötiloissa varastoitujen marinadien välillä ei havaittu selvää eroa pH-arvoissa eikä suola- ja happopitoisuuksissa. Valmisteiden bakteerimäärät olivat melko alhaiset ja pysyivät lähes muuttumattomina koko varastoinnin ajan. Mesofiilien määrät vaihtelivat välillä $59.1-1.52 \times 10^{3} \mathrm{kpl} / \mathrm{g}$ ja halofiilien välillä $1.05 \times 10^{2}-1.19 \times 10^{3}$ kpl/g. Psykrofiilejä ja koliformeja ei näytteistä löydetty. Särkimarinadien rakenne ja maku paranivat hieman varastoinnin aikana. Ulkonäössä ja hajussa ei tapahtunut merkittäviä muutoksia (kuva 4). Ulkonäöstä mainittiin epäkohtana kalojen nahka, mikä teki tuotteesta tumman ja epämiellyttävän näköisen. Tämä epäkohta voitaneen poistaa nylkemällä särjet ennen marinointia. Koska särjet oli kypsennetty ennen marinointia, ne olivat melko pehmeitä ja hajosivat helposti.

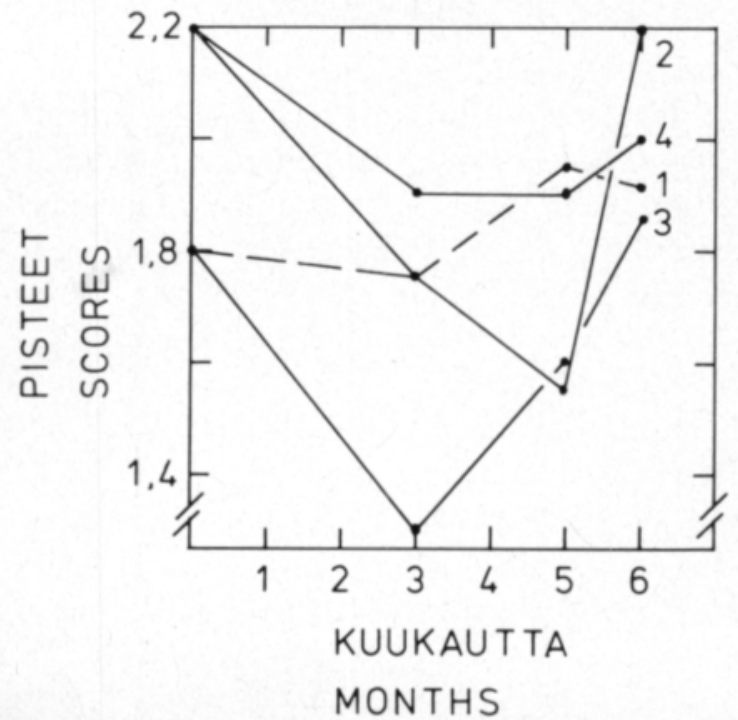

Kuva 4. $10^{\circ} \mathrm{C}$ :ssa marinoidun, lasiastioissa $4^{\circ} \mathrm{C}: s s a$ varastoidun särjen aistinvaraisarvostelussa samat pisteet.

1. ulkonäkö

2. rakenne

3. maku

4. haju

Fig. 4. The scores given in organoleptic evaluation for roach marinated at $10^{\circ} \mathrm{C}$ and stored in glass jars at $4^{\circ} \mathrm{C}$.

1. appearance

2. texture

3. taste

4. aroma 
Ahven.

Seuraavassa tarkastelussa on pidetty vertailuvalmisteena fileerattua $10^{\circ}$ C:ssa raakana marinoitua ahvenmarinadia, jonka valmistuksessa on käytetty lisäaineita ja jota on säilytetty $4^{\circ} \mathrm{C}$ :ssa. Eri tekijöiden vaikutusta on testattu suhteessa tähän valmisteeseen.

Vertailuvalmisteessa kalan suolapitoisuus vaihteli välillä $4.5-5.0 \%$ ja liemen suolapitoisuus välillä $4.9-5.3 \%$. Varastoinnin aikana suolapitoisuuksissa ei tapahtunut suuria muutoksia. Happopitoisuudet olivat kalassa välillä $2.0-2.3 \%$ ja liemessä välillä $2.0-2.2 \%$. Varastoinnin aikana havaittiin lievää happopitoisuuden nousua. Mc LAYn ja PIRIEn (1971) mukaan sillimarinadien happopitoisuus vaihtelee yleensä välillä $1.85-2.50 \%$. Vertailuvalmisteen $\mathrm{pH}$ pysyi varastoinnin ajan välillä $3.86-4.14$. Mesofiilisten ja halofiilisten bakteerien määrät vertailuvalmisteessa olivat melko alhaiset, $40-2.68 \times 10^{2}$ $\mathrm{kpl} / \mathrm{g}$ ja $2.0 \times 10-1.27 \times 10^{3} \mathrm{kpl} / \mathrm{g}$, ja pysyivät lähes muuttumattomina koko varastoinnin ajan. Vertailuvalmisteen aistinvaraisesti arvosteltavassa laadussa ei tapahtunut suuria muutoksia varastoinnin aikana (kuva 5). Ulkonäöltään ahvenfileet olivat kiinteitä ja valkoisia, mutta toisinaan havaittiin kellertäviä värivirheitä tölkeissä päällimmäisinä olleissa fileissä, etenkin jos niitä peitti runsas maustekerros. Rakennetta jotkut maistajat pitivät liian sitkeänä, etenkin heti marinoinnin jälkeen. Maultaan ja hajultaan vertailuvalmiste arvioitiin hyväksi koko varastoinnin ajan, mutta etikan makua pidettiin yleensä hieman liian voimakkaana.

Kuva 5. $10^{\circ} \mathrm{C}$ :ssa lisäaineita käyttäen marinoitujen, lasiastioissa $4^{\circ} \mathrm{C}$ :ssa varastoitujen ahvenfileiden aistinvaraisarvostelussa saamat pisteet. Tunnukset kuten kuvassa 4.

Fig. 5. The scores given in organoleptic evaluation for perch fillets marinated at $10^{\circ} \mathrm{C}$ using preservatives and stored in glass jars at $4^{\circ} \mathrm{C}$. Symbols as in Fig. 4 .

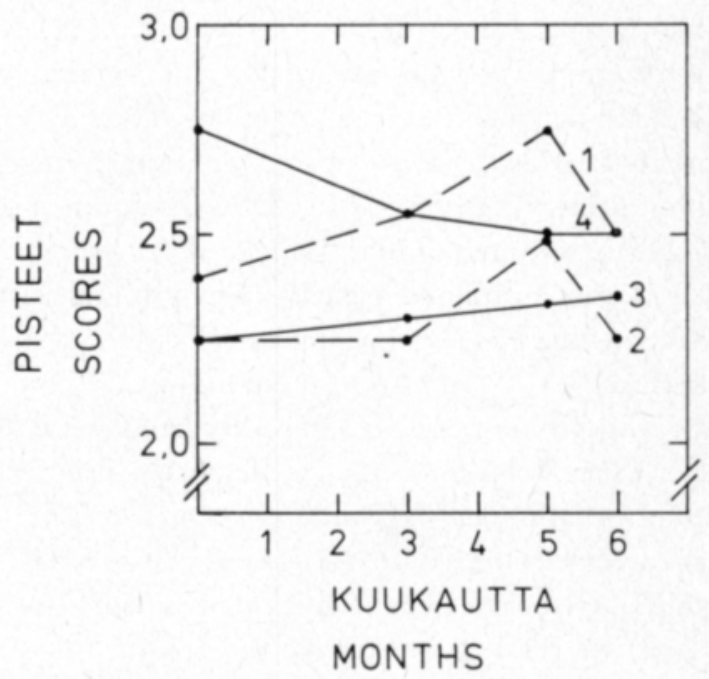

Esikypsennetyn marinoidun ahvenfileen ja vertailuvalmisteen suola- ja happopitoisuudet sekä $\mathrm{pH}$-arvot poikkesivat toisistaan jonkin verran varastoinnin alkaessa, mutta arvot tasoittuivat 6 kuukauden varastoinnin aikana, Mikrobiologisissa määrityksissä ei havaittu eroja esikypsennettynä ja raakana marinoitujen valmisteiden välillä. Esikypsennyksen vaikutus marinoidun ahvenfileen aistinvaraisesti arvosteltaviin ominaisuuksiin on esitetty kuvassa 6. Raakana marinoitujen fileiden rakennetta jotkut maistajista pitivät sitkeänä, mutta esikypsennetyt fileet olivat puolestaan liian pehmeitä. 


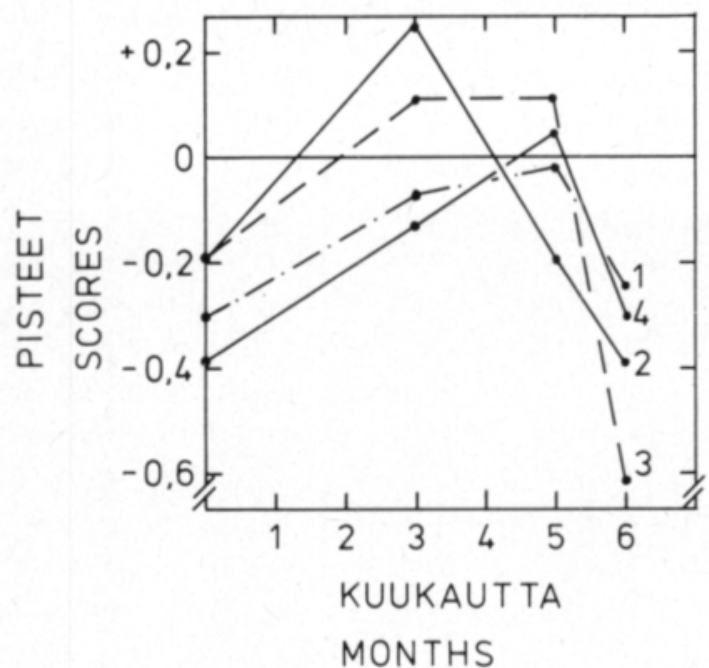

Kuva 6. Esikypsennyksen vaikutus marinoidun ahvenen aistinvaraisarvostelussa saamiin pisteisiin ilmoitettuina poikkeamina vertailuvalmisteen tasosta. Vertailuvalmiste on $10^{\circ} \mathrm{C}$ :ssa lisäaineita käyttäen marinoitu, lasiastiassa $4^{\circ} \mathrm{C}$ :ssa varastoitu ahvenmarinadi. Tunnukset kuten kuvassa 4 .

Fig. 6. The effect of precooking on the scores given in organoleptic evaluation as compared to the reference. The reference is the perch marinated at $10^{\circ} \mathrm{C}$ using preservatives and stored in glass jars at $4^{\circ} \mathrm{C}$. Symbols as in Fig. 4.

Eri lämpötiloissa, $10^{\circ} \mathrm{C}$ :ssa ja $20^{\circ} \mathrm{C}$ :ssa, marinoitujen ahventen suola- ja happopitoisuuksissa ei havaittu merkitseviä eroja. Heti marinoinnin jälkeen $\mathrm{pH}$-arvot olivat $10^{\circ} \mathrm{C}$ :ssa marinoiduissa kaloissa hieman alhaisemmat kuin $20^{\circ} \mathrm{C}$ :ssa marinoiduissa, mutta varastoinnin aikana erot hävisivät. Säilyvyyskokeiden alkaessa olivat mesofiilisten bakteerien määrät $20^{\circ} \mathrm{C}$ :ssa marinoiduissa kaloissa korkeammat kuin $10^{\circ} \mathrm{C}$ :ssa marinoiduissa, mutta myöhemmin varastoinnin aikana erot pienenivät. Halofiilien määrät olivat molemmissa ryhmissä yhtä suuret koko varastoinnin ajan. Testattaessa marinointilämpötilojen aiheuttamia eroja triangelitestillä havaittiin tilastollisesti merkittävä ero $1 \%$ :n tasolla heti marinoinnin jälkeen. Korkeammassa lämpötilassa marinoidun kalan rakenne oli pehmeämpi ja maku etikkaisempi kuin alhaisemmassa lämpötilassa marinoidun. Varastoinnin aikana erot kuitenkin tasoittuivat. Erot heti marinoinnin jälkeen johtunevat siitä, että korkeammassa lämpötilassa marinoidussa kalassa kypsyminen oli edennyt pidemmälle marinoinnin aikana kuin $10^{\circ} \mathrm{C}$ :ssa marinoidussa kalassa, joka saavutti saman kypsyysasteen vasta varastoinnin aikana.

Natriumbentsoaatin ja p-hydroksibentsoehapon metyyliesterin käyttö säilöntäaineina ei vaikuttanut marinadien bakteerimääriin eikä $\mathrm{pH}$-arvoihin varastoinnin aikana. Ulkonäössä, rakenteessa, maussa ja hajussa ei aistinvaraisarvostelussa havaittu suuria eroja (kuva 7). Triangelitestillä ei havaittu tilastollisesti merkitseviä eroja lasi- ja muovitölkeissä varastoitujen ahvenmarinadien välillä. Muovitölkkeihin pakatuissa kaloissa havaittiin kellertäviä ja ruskeita värivirheitä useammin kuin lasitölkkeihin pakatuissa. Jotkut maistajista havaitsivat muovitölkkeihin pakatuissa marinadeissa lievää sivumakua 6 kuukauden varastoinnin jälkeen. Säilytyslämpötila $\left(4^{\circ} \mathrm{C}\right.$ ja $\left.10^{\circ} \mathrm{C}\right)$ ei vaikuttanut tuotteiden suola- ja happopitoisuuksiin eikä $\mathrm{pH}$-arvoihin. Bakteerimäärät olivat koko kokeen ajan samaa suuruusluokkaa sekä $4^{\circ} \mathrm{C}$ :ssa että $10^{\circ}$ C:ssa varastoiduissa ahvenmarinadeissa. Aistinvaraisarvostelussa saatiin triangelitestillä ilman lisäaineita marinoidun lasiastiassa varastoidun ahvenmarinadin kohdalla merkitsevä ero $5 \%$ :n tasolla 3 kuukauden säilytyksen jälkeen ja $1 \%$ :n tasolla 6 kuukauden säilytyksen jälkeen. $4^{\circ} \mathrm{C}$ :ssa säilytettyjä valmisteita 
pidettiin yleensä voimakkaamman makuisina kuin $10^{\circ} \mathrm{C}$ :ssa säilytettyjä. Rakenne oli korkeammassa lämpötilassa varastoiduissa kaloissa pehmeämpi kuin alhaisemmassa lämpötilassa varastoiduissa.

Kuva 7. Ilman lisäaineita $10^{\circ} \mathrm{C}$ :ssa marinoidun, lasiastiassa $4^{\circ} \mathrm{C}$ :ssa varastoidun ahvenen aistinvaraisarvostelussa saamat pisteet ilmoitettuina poikkeamina vertailuvalmisteen tasosta. Tunnukset kuten kuvassa 4.

Fig. 7. The scores given in organoleptic evaluation for perch fillets marinated at $10^{\circ} \mathrm{C}$ without preservatives and stored in glass jars at $4^{\circ} \mathrm{C}$ as compared to the reference. Symbols as in Fig. 4.

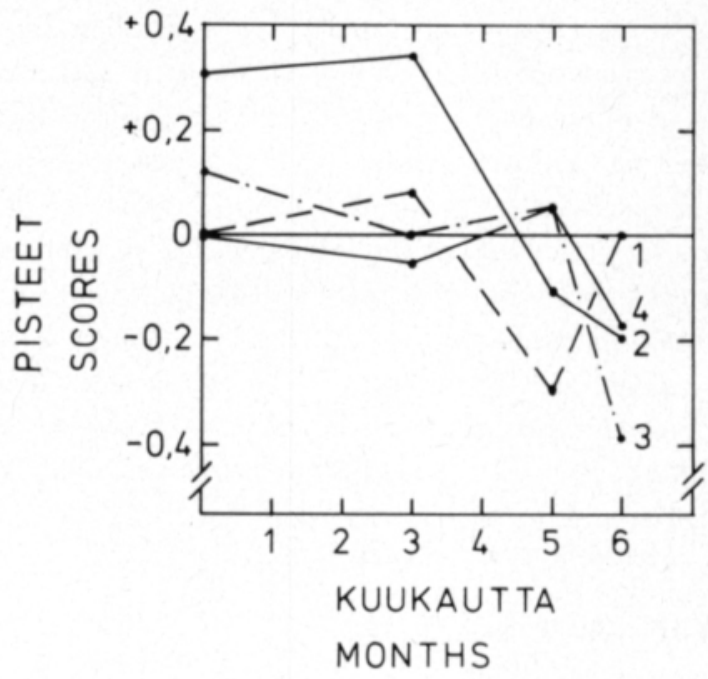

\section{Tulosten tarkastelu}

Tulosten perusteella voidaan todeta, että käytetyllä menetelmällä voidaan ahvenesta ja särjestä valmistaa säilyvä, laadultaan hyväksyttävä marinadi. Ahvenmarinadeja pidettiin maultaan selvästi särkimarinadeja parempina. Monien maistajien mielestä liian voimakas etikan maku on todennäköisesti peitettävissä sokeria lisäämällä tai käyttämällä erilaisia mausteseoksia. Pakattaessa marinoituja kaloja varastointiastioihin voidaan käytetyn marinointiliemen tilalle valmistaa uusi etikka-, suola- ja sokeripitoisuuksiltaan alkuperäisestä poikkeava liemi. Käytettäessä uutta lientä vähenee myös säilyketölkin pohjalle erottuvan valkoisen proteiinisakan määrä. Sakka voidaan poistaa myös suodattamalla alkuperäinen liemi ennen varastointiastioihin kaatamista. Kaupallisessa valmistuksessa myyntiastioihin lisätään usein uusi vastavalmistettu liemi, jossa on 1-2\% etikkahappoa ja $2-4 \%$ suolaa sekä mausteita (MEYER 1965).

Särkimarinadien hieman epämiellyttävää ulkonäköä voidaan parantaa nylkemällä kalat ennen marinointia. Nahattomien särkifileiden marinointia raakana ilman esikypsennystä voitaisiin myös ajatella, koska kuumennuskäsittely tekee kalat pehmeiksi ja helposti hajoaviksi.

Varastoinnin aikana marinadien laadussa ei tapahtunut tilastollisesti merkitseviä muutoksia. Bakteerimäärät pysyivät koko ajan melko alhaisina eikä eri ryhmien välillä ollut merkitseviä eroja. Kokeiltaessa kahta eri lämpötilaa, $10^{\circ} \mathrm{C}$ ja $20^{\circ} \mathrm{C}$, kypsymisen havaittiin olevan hieman nopeampaa korkeammassa lämpötilassa tarvittavien kypsytysaikojen ollessa 4 vrk $20^{\circ} \mathrm{C}$ :ssa ja 5 vrk $10^{\circ} \mathrm{C}$ :ssa. Heti marinoinnin jälkeen korkeammassa lämpötilassa marinoidut kalat olivat pehmeämpiä ja maistuivat voimakkaammin etikalta kuin alhaisemmassa lämpötilassa marinoidut, mutta varastoinnin aikana eroja ei enää havaittu. 
Säilytyslämpötilan ei havaittu vaikuttavan tuotteiden bakteerimääriin ja $\mathrm{pH}$-arvoihin. Lasi- ja muovitölkkeihin pakattujen säilykkeiden välillä $\epsilon \mathrm{i}$ ollut merkitseviä eroja, mutta muutamien maistajien mielestä muovitölkeissä varastoiduissa kaloissa oli lieviä sivumakuja 6 kuukauden säilytyksen jälkeen.

Käytetyillä lisäaineilla, natriumbentsoaatilla ja p-hydroksibentsoehapon metyyliesterillä, ei ollut vaikutusta säilyvyyteen. MEYERin (1965) mukaan vain heksametyleenitetramiini on kyllin tehokas lisäaine estääkseen mikrobien kasvua kalamarinadeissa. Nykyisin sen käyttöä ei kuitenkaan suositella formaldehydin muodostumisen vuoksi. Kokeet bentsoehaposta ovat osoittaneet, että käytettäessä riittävän korkeata konsentraatiota mikrobikasvun ehkäisemiseksi havaitaan kalassa makuvirheitä. Kylmämarinadien pääasiallisia pilaajaorganismeja ovat heterofermentatiiviset maitohappobakteerit. Niiden ehkäisemiseksi tarvitaan suhteellisen korkea happopitoisuus ja alhainen varastointilämpötila, koska niiden kasvun optimilämpötila on $30^{\circ} \mathrm{C}$ (MEYER 1965). Ahven- ja särkimarinadien $\mathrm{pH}$ oli riittävän alhainen näiden pilaajaorganismien kasvun estymiseksi.

\section{Yhteenveto}

Tutkimuksessa etsittiin optimaaliset prosessointiolosuhteet ahvenen ja särjen marinointia varten. Säilyvyyden ja maun kannalta optimaaliset etikkaja suolakonsentraatiot sekä marinointiaika $10^{\circ} \mathrm{C}: \mathrm{n}$ ja $20^{\circ} \mathrm{C}: n$ lämpötiloissa etsittiin sekä pienille $(10-40 \mathrm{~g})$ että isoille $(100-300 \mathrm{~g})$ ahvenille ja särjille. Säilyvyyskokeet kestivät 6 kuukautta ja ne tehtiin pienestä särjestä ja isosta ahvenesta valmistetuilla marinadeilla. Marinointilämpötilan, lisäaineiden käytön, pakkausmateriaalin ja varastointilämpötilan vaikutusta tuotteen laatuun ja säilyvyyteen tutkittiin.

Sopivat marinointiajat olivat $10^{\circ} \mathrm{C}: \mathrm{n}$ ja $20^{\circ} \mathrm{C}$ :n lämpötiloissa isoilla ahvenfileillä 5 ja 4 vuorokautta, esikypsennetyillä isoilla ahvenfileillä 2 ja 1 vuorokautta, peratulla isolla särjellä 6 ja 5 vuorokautta sekä nyljetyllä pienellä ahvenella ja isolla särkifileellä 3 vuorokautta ja esikypsennetyllä pienellä särjellä 2 vuorokautta $10^{\circ} \mathrm{C}: n$ lämpötilassa.

Varastoinnin aikana marinadien laadussa ei tapahtunut merkitseviä muutoksia. $\mathrm{pH}$ oli kaikissa valmisteissa alle 4.5 ja bakteerimäärät pysyivät melko alhaisina koko varastoinnin ajan. Heti marinoinnin jälkeen korkeammassa lämpötilassa marinoidut kalat olivat pehmeämpiä ja maistuivat voimakkaammin etikalta kuin alhaisemmassa lämpötilassa marinoidut, mutta varastoinnin jälkeen eroja ei enää havaittu.

Ahvenmarinadeja pidettiin yleensä särkimarinadeja parempina. Etikan maku oli kaikissa valmisteissa hieman liian voimakas. Raakana marinoituja kaloja pidettiin heti marinoinnin jälkeen hieman sitkeinä, mutta varastoinnin aikana niiden rakenne pehmeni. Esikypsennys ennen marinointia teki kalat liian pehmeiksi ja helposti hajoaviksi.

Säilytyslämpötilan ei havaittu vaikuttavan tuotteiden bakteerimääriin ja pH-arvoihin. Käytetyillä lisäaineilla, natriumbentsoaatilla ja p-hydroksibentsoehapon metyyliesterillä ei ollut vaikutusta säilyvyyteen. Lasi- ja muoviastioihin pakattujen marinadien välillä ei ollut merkitseviä eroja. 


\section{Kiitokset}

Tutkimuksen on rahoittanut Suomen Luonnonvarain Tutkimussäätiö ja sitä on johtanut tutkimusryhmä, johon kuuluvat prof., MMT Pekka Koivistoinen, Helsingin yliopisto, elintarvikekemian ja -teknologian laitos (puheenjohtaja), apul. prof., TkT Rakel Kurkela, Helsingin yliopisto, elintarvikekemian ja -teknologian laitos, toiminnanjohtaja, MMK Lauri Liedes, Suomen Kalastusyhdistys, lehtori, DI Aimo Kosonen, Helsingin yliopisto, elintarvikekemian ja -teknologian laitos, ylitarkastaja, agr. Marjatta Lahtinen, Ammattikasvatushallitus ja ylitarkastaja, ELL Pentti Sippo, Lääkintöhallitus. Asiantuntijoina ovat toimineet dos., MMT Jorma Laine, Helsingin yliopisto, elintarvikekemian ja -teknologian laitos ja prof., MMT Reino Ryhänen, Helsingin yliopisto, limnologian laitos.

\section{KIRJALLISUUSLUETTELO}

Antonacopoulos, N. 1973. Untersuchungsverfahren (Sensorik, Chemie). In Fische und Fischerzeugnisse. p. 202-237. Ed. W. Ludorf \& V. Meyer, 2nd Ed. Berlin.

Borgström, G. 1965. Fish as Food. Vol. 3. 489 p. New York.

Gyllenberg, H., LAine, $\mid$. \& NiemelÄ, S. 1966. Elintarvikkeiden mikrobiologian laboratorioopas. 83 p. Helsinki.

LUdorf, W. \& MEYer, V. 1973. Fische und Fischerzeugnisse. 309 p. 2nd Ed. Berlin.

MCLAY, R. \& PirIE, R. 1971. Development of marinated herring. J. Food. Technol. 6: 29-38.

MeYer, V. 1965. Marinades. In Fish as Food. 3. p. 165-193. Ed. G. Borgström. New York.

Sharf, J. M. 1966. Recommended Methods for the Microbiological Examination of Foods. 205 p. 2nd Ed. New York.

Käsikirjoitus saapunut 5.6.1978 